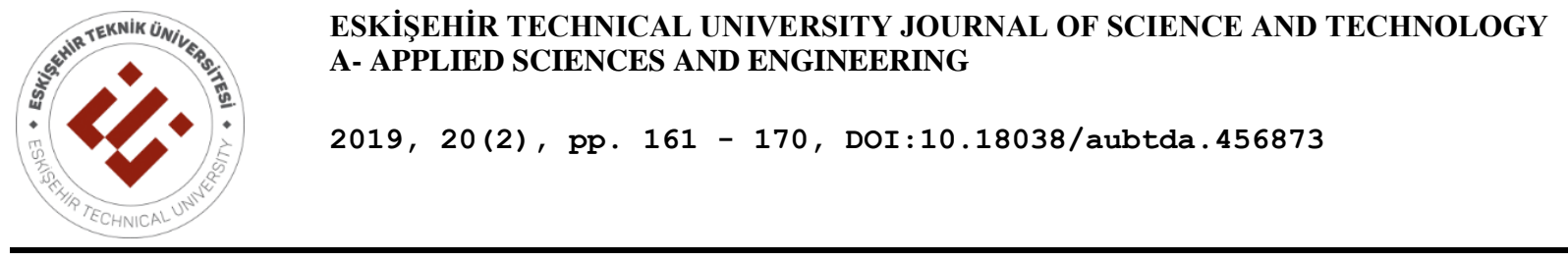

\title{
ENERGY RECOVERY FROM ANIMAL MANURE: BIOGAS POTENTIAL OF BURDUR, TURKEY
}

\author{
Zuhal AKYÜREK* \\ Department of Polymer Engineering, Faculty of Engineering and Architecture, \\ Burdur Mehmet Akif Ersoy University, Burdur, Turkey
}

\begin{abstract}
Sustainable development depends on the availability of energy resources and their impact on environment. Biogas is a carbon neutral renewable energy option and one of the leading solutions to the climate change combat. As Turkey is an energy importer country, using indigenous energy sources is vital to meet future energy demand. Agricultural activities and livestock potential have high contribution to economy in Turkey. Biogas production from organic wastes such as livestock manure in this context, gain more importance to contribute both renewable energy production and waste management strategies. Livestock farming has important economic value in Burdur. In this regard, the animal manure based biogas potential, energy value, electricity and organic fertilizer generation capacity of Burdur Province were determined in this study. The results revealed that Burdur has annually 1.45 million tons of available animal manure potential to be used for biogas production of $27.1 \mathrm{million} \mathrm{m}^{3} /$ year. This potential corresponds to $135.4 \mathrm{GWh}$ annual energy generation that could be converted to heat and electricity. Considerable amount of the biogas production capacity has accumulated in the Center and, Bucak, Yeşilova, Gölhisar and Karamanlı districts of Burdur. In addition, about 50776 tons/year of organic fertilizer can be produced as the residual of the biogas plants.
\end{abstract}

Keywords: Animal manure, Biogas, Burdur, Renewable energy, Waste management

\section{INTRODUCTION}

Progressive depletion of world fossil fuel reserves, increase in global energy demand and the negative environmental impacts of fossil fuel combustion have led to a shift toward renewable energy alternatives. Especially, the fluctuations in energy prices have highly motivated countries to search for renewable energy solutions. Among the renewables, biomass is the only energy source which can deliver electricity, provide heating, cooling and used as fuel in solid, liquid and gaseous forms [1]. Biomass has attracted more attention in recent years as a low risk and capital required renewable energy source [25]. Biomass refers to carbonaceous materials derived from agricultural crops, forestry, agro-industrial and domestic wastes. It is ranged as the fourth primary energy source after coal, oil and natural gas [6]. The share of biomass accounts for $14 \%$ in the world global energy mix [7].

Several energy conversion methods such as gasification, pyrolysis, combustion, anaerobic digestion, etc. have been developed in field of biomass energy [8-10]. Anaerobic Digestion (AD) which is defined as the biochemical degradation of organic material has become as one of the most favorable renewable energy pathway for utilization of biomass [11]. Biogas is produced from anaerobic digestion of organic materials such as urban, industrial, livestock and agricultural wastes. Biogas is a colorless and odorless flammable gas. Typical biogas characteristics is shown in Table 1. It mainly consists of methane, carbon dioxide and hydrogen as well as particulates and contaminants with trace amounts [12].

*Corresponding Author:drzuhalakyurek@gmail.com

Receiving: 03.09.2018 Accepted: 30.04.2019 
Table 1. Biogas composition [12-14]

\begin{tabular}{cc}
\hline Components & Share, \% \\
\hline $\mathrm{CH}_{4}$ & $50-70$ \\
$\mathrm{CO}_{2}$ & $25-50$ \\
$\mathrm{~N}_{2}$ & $0-10$ \\
$\mathrm{H}_{2}$ & $0-0.1$ \\
$\mathrm{H}_{2} \mathrm{~S}$ & $0-0.3$ \\
$\mathrm{O}_{2}$ & $0-0.2$ \\
\hline Calorific Value & $21-24 \mathrm{MJ} / \mathrm{m}^{3}$ \\
\hline
\end{tabular}

Biogas can be directly combusted and converted to heat and/or electricity or can be upgraded to pure methane so called as renewable natural gas or bio-methane by purification of water, carbon dioxide, hydrogen sulfide, and other trace contaminants. Hence, being a similar energy carrier to natural gas, biogas can be connected to the gas network [15].

The anaerobic digestion of organic wastes is an alternative treatment method with significant advantages over other processes, such as waste management, environmental protection and power generation from biogas [16]. Manure waste from livestock farming is recognized as a cost-effective feedstock for biogas production. Besides green energy production, utilization of manure through anaerobic digestion provides prevention from unpleasant odors and microbial pathogens, production of nutrient rich organic fertilizers and reduction of non-carbon dioxide greenhouse gas emissions such as methane and nitrous oxide in comparison with the conventional manure management strategies [17, 18].

Many factors influence stability and biogas yield of anaerobic digestion process of livestock manure such as $\mathrm{pH}$, process temperature, retention time in the reactor, etc. Mesophilic anaerobic digestors ideally work at neutral $\mathrm{pH}$ and temperature at around $30-40{ }^{\circ} \mathrm{C}$. Carbon to nitrogen ratio $(\mathrm{C} / \mathrm{N})$ of the feedstock is also an important factor. It is suggested that $\mathrm{C} / \mathrm{N}$ ratio in the range of 14-20 is acceptable for anaerobic digestion process [19-20]. Co-digestion with different organic materials could help to provide optimum ratio [21].

The production of biogas from anaerobic digestion is of growing interest in many countries to reduce greenhouse emission reduction. In Europe, biogas is predicted to play an important role in achieving energy policy targets of the European Union (EU) for year 2050. Germany is the leading country in biogas production, corresponding to $50 \%$ of the total production in Europe [22]. In Turkey's Intended Nationally Determined Contribution [23], covering the period 2012-2030, it is stated total greenhouse gas emissions will be reduced up to $21 \%$ by 2030 with the improvements in energy, industrial processes and products use, agriculture, land use, land-use change and forestry, and waste sectors. Turkey has also announced a reduction in greenhouse gas emissions from 1175 to 929 million ton $\mathrm{CO}_{2}$ equal in 2030 in The Tenth Development Plan (2014-2018) [24] by pointing out the prior actions to address the issues of climate change and environmental pollution, with regard to solid waste disposal and recycling. Renewable energy infrastructure investments for waste disposal (biogas, biomass and MSW combustion, heat recovery) will be encouraged with financial support mechanisms for energy companies, collective housing administrations and municipalities. In Turkey, the installed capacity of biomass based power plants are about $0.63 \mathrm{GW}$ [25]. The highest capacity biogas plants are presented in Table 2. 
Table 2. The highest capacity biogas power plants in Turkey [26]

\begin{tabular}{llc}
\hline Company & Province & Installed capacity, MW \\
\hline Odayeri Biogas Power Plant & Istanbul & 34 \\
Mamak Garbage Biogas Power Plant & Ankara & 25 \\
Çadirtepe Biomass Power Plant & Ankara & 23 \\
Sofulu Garbage Biogas Power Plant & Adana & 16 \\
Kömürcüoda Garbage Biogas Power Plant & Istanbul & 14 \\
Başfaş Fertilizer Biogas Power Plant & Balıkesir & 9.92 \\
Hamitler Garbage Biogas Power Plant & Bursa & 9.80 \\
Avdan Biogas Power Plant & Samsun & 6 \\
Modern Biomass Energy Power Plant & Tekirdağ & 6 \\
Afyon Energy Biogas Power Plant & Afyonkarahisar & 4 \\
\hline
\end{tabular}

In order to fulfill the carbon dioxide reduction obligations and prevent the adverse environmental impacts of wastes, indigenous sources shall be utilized to produce renewable energy in Turkey. In this manner assessing the potential of available resources gain importance in order to contribute alternative electricity production from animal manure and waste management efforts. In many countries biogas potential estimation studies have carried out for various type of animal wastes [27-29].

In Turkey, livestock farming has high economic value signifying high animal manure potential for biogas production. The total livestock biogas potential of Turkey is originated from $68 \%$ cattle, 5\% small ruminant and $27 \%$ poultry [30]. In this study, animal manure based biogas potential is determined for Burdur Province. Burdur is located in the West Mediterranean Region of Turkey. Burdur province has total land area of 717500 hectares and its ranked 48th in terms of land size in Turkey. The city has interior Mediterranean climate which is usually characterized by cold, snowy winters and hot, dry summers. The livestock farming has high contribution to economy of the city. Collection, storage and disposal of animal manure are the major problems of local livestock farmers in Burdur. Manure storage and handling systems are essential for manure management. Distributed allocation and high number of small capacity livestock farms and also lack of manure storage tanks harden the utilization of these wastes. The amount of animal waste production in the province is high and requires effective management strategies. Dairy and meat cooperatives and the renewable energy investors show particular interest in biogas production but there are still no biogas plants operating in Burdur. There are a number of studies for estimating the biogas potential in different provinces in Turkey from variety of wastes [30-33], however there are no studies available for biogas potential for Burdur Province and its districts. Therefore, this study attempts to identify the biogas potential of Burdur considering animal manure capacity using recent data to assess the utilization of the waste in terms of biogas production, energy generation, organic fertilizer production and its benefits in terms of public health and comfort for promoting the biogas investments.

\section{MATERIALS AND METHODS}

In this study, the animal manure based biogas potential of Burdur province center and its ten districts including Bucak, Yeşilova, Gölhisar, Karamanlı, Çavdır, Kemer, Tefenni, Çeltikçi, Ağlasun and Altınyayla have estimated. The locations of the districts are illustrated in the geographic map of Burdur in Figure 1. The total number of cattle, small ruminant and poultry are provided from Burdur Directorate of Provincial Agriculture and Forestry [34]. Burdur has the highest number of cattle in Mediterranean Region [35]. Total number of animals in Burdur province is 644,611 (2017). The total share of animal types of in Burdur in terms of cattle, small ruminant and poultry are $36 \%, 64 \%$ and $3 \%$, respectively. The distribution of number of animals is shown in Figure 2. These numbers were then used to calculate the amount of animal waste potential and biogas potential for all the districts. 


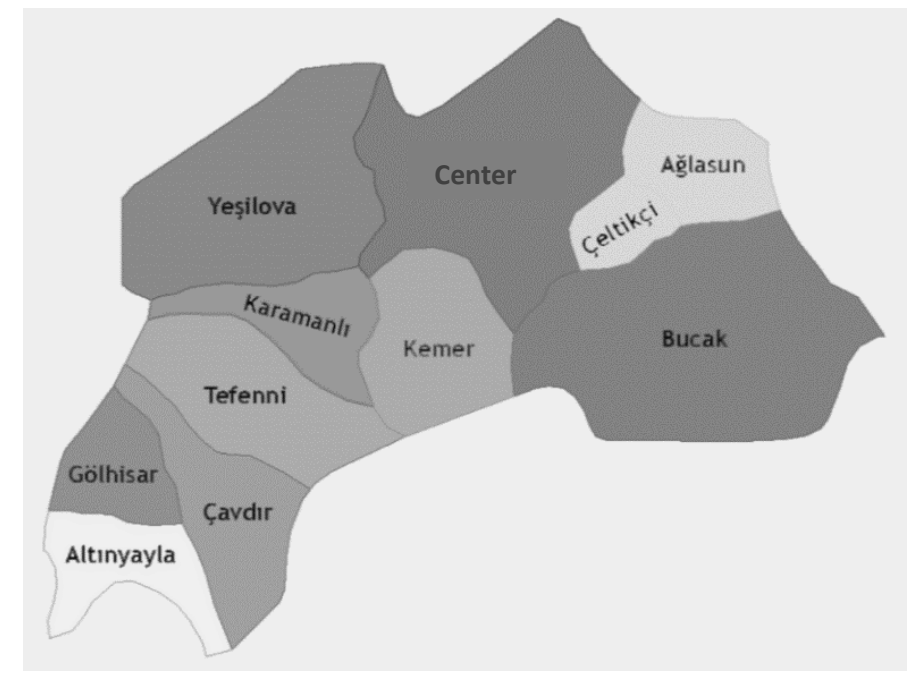

Figure 1. Geographic distribution of the districts in Burdur

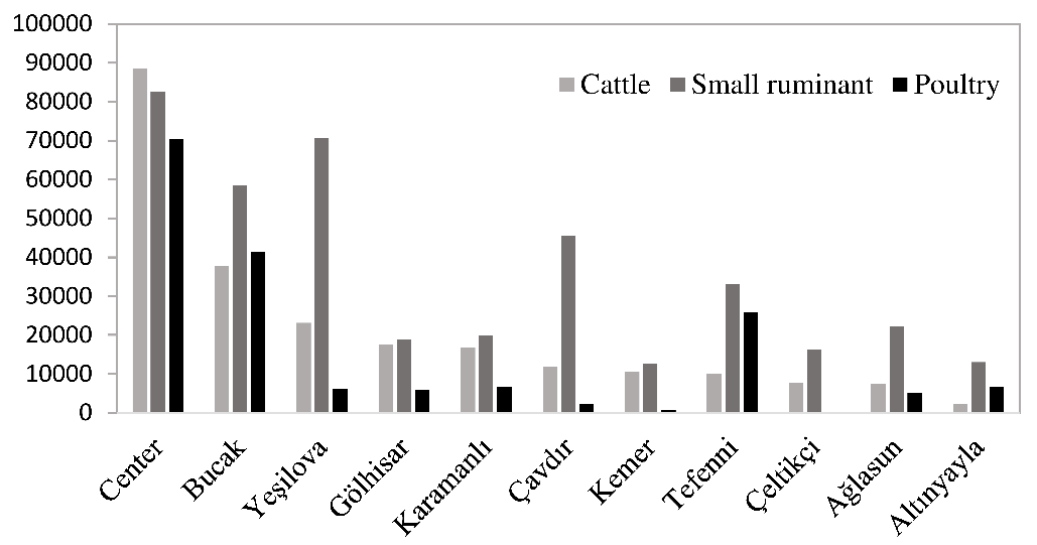

Figure 2. Cattle, small ruminant and poultry population in districts of Burdur

As can be seen from the figure, Center of Burdur and Bucak district have higher existence of animal stock in terms of cattle compared with the animal population in other districts. Many factors affect the amount of waste and biogas potential in the livestock operations. These are the type of animal, animal body weight, total solids ratio, volatile solids ratio, the availability ratio of waste and biogas yields. Table 3 shows the waste characteristics of the livestock. Availability of waste is an important factor that needs to be taken into account in determining the biogas potential from animal wastes. By taking into account the residence time of the animals in the shelter, the availability or collectability ratio was taken as $65 \%$ for cattle, $13 \%$ for small ruminants, $99 \%$ for poultry [30].

As can be seen from Table 3, the amount of biogas evolved during anaerobic digestion of the animal manure varies according to the animal type. Therefore, the biogas yield of different kinds of manure have been considered during calculations of biogas potential. The average values have been used in calculations.

Table 3. Waste Characteristics by type of animals $[30,36]$

\begin{tabular}{lllll}
\hline Animal Type & Manure (kg/day) & $\begin{array}{l}\text { TS \% } \\
\text { (Total Solids) }\end{array}$ & $\begin{array}{l}\text { VTS \% } \\
\text { (Volatile Total Solids) })\end{array}$ & $\begin{array}{l}\text { Biogas Yield } \\
\left(\mathrm{m}^{3} / \mathrm{kg} \text { VTS }\right)\end{array}$ \\
\hline Cattle & $10-25$ & $10-20$ & $75-85$ & $100-300$ \\
Small Ruminant & $2-4$ & $25-30$ & $70-80$ & $10-50$ \\
Poultry & $0.05-1.0$ & $40-60$ & $60-80$ & $300-500$ \\
\hline
\end{tabular}


Theoretical biogas amount generated from the manure is calculated from Equation 1:

$$
T P B=M \times T S \times V T S \times A C \times E B_{V T S}
$$

where TPB denotes the theoretical potential of biogas $\left(\mathrm{m}^{3} /\right.$ year),

$\mathrm{M}$ is the total amount of the manure produced for each city ( $\mathrm{kg} / \mathrm{year}$ )

TS represents the ratio of the total solids of the animal manure,

VTS is the volatiles ratio in total solids of the waste,

$\mathrm{AC}$ denotes the availability $\%$ and

$\mathrm{EB}_{\mathrm{VTS}}$ is the quantity of estimated biogas produced per $\mathrm{kg}$ of the volatile total solids $\left(\mathrm{m}^{3} / \mathrm{kg}\right.$ VTS)

The amount of energy produced from bio-methane $(\mathrm{kWh} /$ year) is calculated based on Equation 2;

$$
E_{M}=T B P * M_{p} * E_{C H_{4}}
$$

$\mathrm{M}_{\mathrm{P}}$ represents the methane production ratio of biogas \%

$\mathrm{E}_{\mathrm{CH} 4}$ is the energy content of methane, $36 \mathrm{MJ} / \mathrm{m}^{3} \mathrm{CH}_{4}$ [37]

The fermentation process reduces the organic dry matter content of original material to 24-80\% [38].

\section{RESULTS AND DISCUSSION}

Animal manure is an important public health and waste management problem in Burdur in relation with high economic contribution of livestock farming activities in the province. The animal stock is distributed in a wide land area therefore, collectability and storage of manure are major obstacles for utilization of animal waste. In this section, the theoretical potential of biogas production from different types of animal manure in Burdur province was estimated. The amount of animal waste production from different districts in Burdur province according to the data recorded at the end of 2017 is shown in Table 4. The results revealed that Burdur province has total 27.1 million $\mathrm{m}^{3} /$ year biogas production potential. This is an indicative of efficient management of livestock farms could be further processed in the biogas plants for renewable energy production and environmental protection. The distribution of this potential within the districts has demonstrated in Figure 3. As can be seen from the Table 4 and Figure 3, Central part of Burdur province, Bucak, Yeşilova, Gölhisar and Karamanlı districts have huge animal manure potential for biogas production.

Table 4. Available animal manure potential and biogas potential in Burdur and districts (2017)

\begin{tabular}{lcc}
\hline District & $\begin{array}{c}\text { Animal Manure Potential } \\
\text { tons/year }\end{array}$ & $\begin{array}{c}\text { Biogas Potential } \\
\mathbf{1 0 0 0} \mathbf{~ m}^{3} / \text { year }\end{array}$ \\
\hline Center & 554768.5 & 10371 \\
Bucak & 235121.5 & 4349 \\
Yeşilova & 141444.2 & 2659 \\
Gölhisar & 106423.5 & 1983 \\
Karamanlı & 101075.6 & 1899 \\
Çavdır & 74796.5 & 1380 \\
Tefenni & 64360.3 & 1218 \\
Kemer & 63941.5 & 1205 \\
Çeltikçi & 46711.9 & 863 \\
Ağlasun & 46640.7 & 854 \\
Altınyayla & 15462.1 & 290 \\
\hline TOTAL & 1450746.2 & 27071 \\
\hline
\end{tabular}




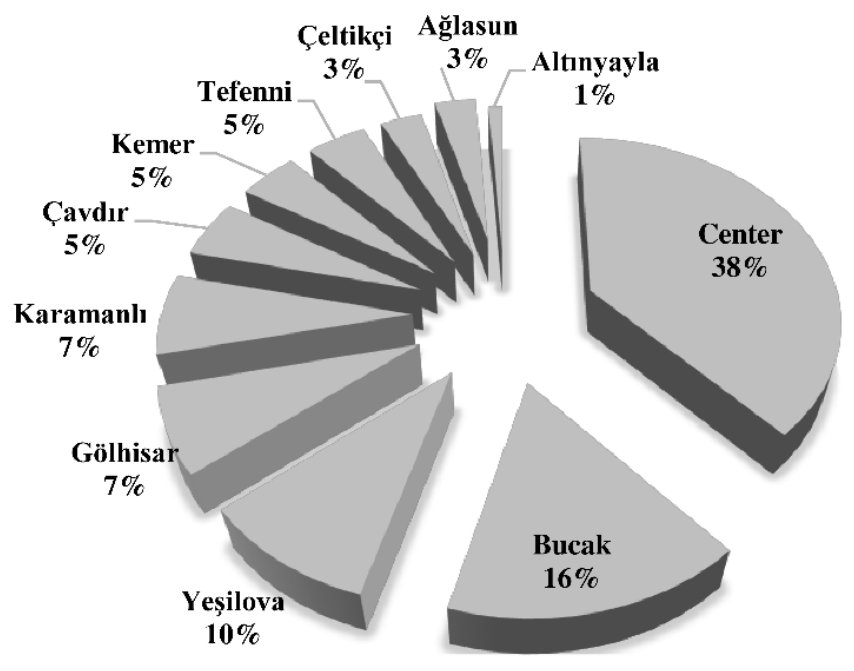

Figure 3. Distribution of the biogas potential in Burdur districts

The discharge of the livestock waste contaminates the environment with high levels of pathogens, endangering the human and animal health. For renewable energy production and ensuring a healthy environment it is necessary to progressively adopt the environmentally friendly biogas technology. Compared to the provinces located in the Mediterranean Region, Burdur province has the highest number of cattle farming and hence cattle manure potential. Therefore, cattle manure derived potential of biogas production is the highest among the other provinces in the region. (Figure 4). Biomethane can be integrated to the natural gas grid, used for domestic cooking, heat and power generation or turn into vehicle fuel [11]. The results signify high potential of biogas production in Burdur.

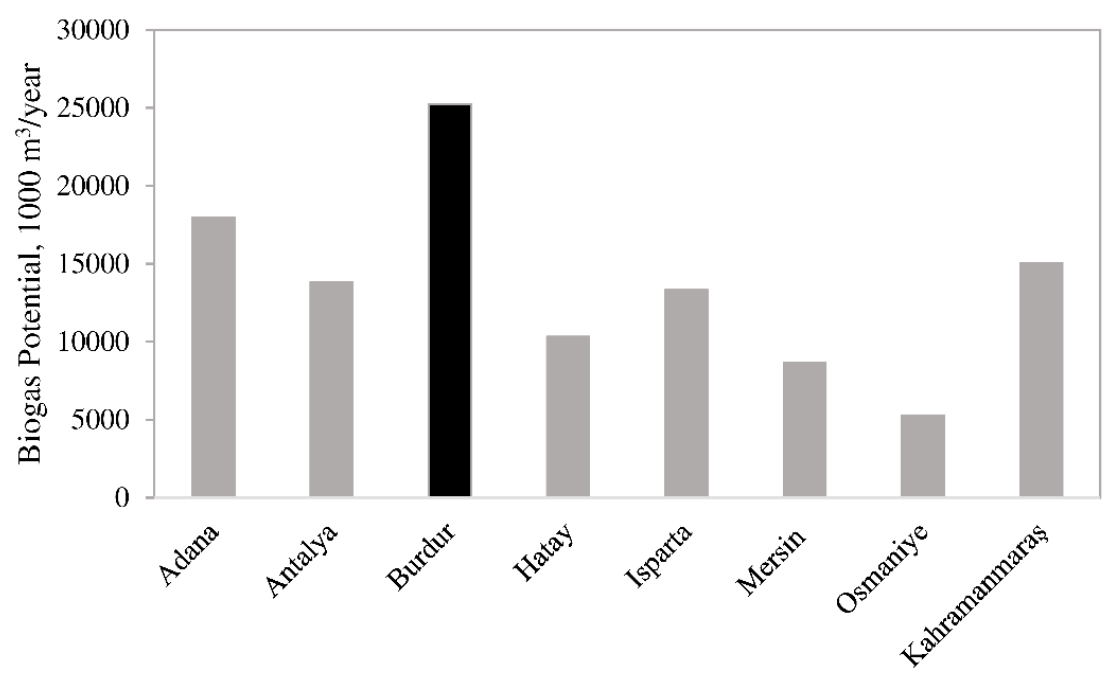

Figure 4. Cattle manure derived biogas potential of provinces in Mediterranean Region of Turkey [35]

The biogas energy potential of Burdur province corresponds to $135.4 \mathrm{GWh}$ annual energy generation potential to be converted to heat and electricity. The energy capacity of the districts of Burdur is presented in Table 5. 
Table 5. The biogas energy potential in the districts of Burdur.

\begin{tabular}{lc}
\hline District & $\begin{array}{c}\text { Energy Generation } \\
\text { Capacity }\end{array}$ \\
\hline MWh/year \\
\hline Benter & 51854.3 \\
Yucak & 21743.7 \\
Geşilova & 13295.6 \\
Karlhisar & 9916.7 \\
Çavdır & 9494.7 \\
Tefenni & 6897.5 \\
Kemer & 6091.6 \\
Çeltikçi & 6025.7 \\
Ağlasun & 4317.3 \\
Altınyayla & 4270.5 \\
\hline TOTAL & 1449.6 \\
\hline
\end{tabular}

The residual of the biogas production plant is organic fertilizer, rich in nutrients and nitrogen, offers an attractive alternative to commercial fertilizers. The digested substrate can be dewatered by solar drying or solid-liquid separators to produce high-quality organic fertilizer. Liquid removal from the digestate also provides reduction in transportation costs [39]. In Burdur province annually about 50776 tons of organic fertilizer can be produced from biogas plants to increase the efficiency of the agricultural lands.

\section{CONCLUSION}

Concerns on rapid depletion of energy resources and the need for mitigation of adverse environmental impacts of energy generation from fossil based fuels have increased the deployment of renewable energy carriers such as biogas. Biogas from animal waste could be a feasible option for provinces whose economy strongly depends on livestock farming. Through sustainable research programs, the anaerobic digestion technology for biogas production from animal manure can be poised for commercial applications in Burdur. This paper proposed to identify the theoretical potential of the energy generation through biogas derived from animal waste in Burdur province located in Mediterranean Region of Turkey. The estimated biogas potential in the province is obtained as 27.1 million $\mathrm{m}^{3} / y e a r$ corresponds to annual 135.4 GWh energy generation. Among the districts of Burdur, central part of the province has the highest biogas potential followed by Bucak, Yeaşilova, Gölhisar and Karamanlı districts.

In conclusion, biogas produced from livestock manure could be one of the significant sources of renewable energy production and solution to animal waste management problem in Burdur province. The findings of this study provide key information to investors that consider biogas investments in the province. Animal waste potential of Burdur is remarkable and farmers and investors can make use of benefits of waste to energy technologies if properly managed and supported by governmental subsidies.

\section{ACKNOWLEDGEMENTS}

This research did not receive any specific grant from funding agencies in the public, commercial, or notfor-profit sectors. 


\section{REFERENCES}

[1] Maghanaki MM, Ghobadian B, Najafi G, Janzadeh Galogah R, Potential of biogas production in Iran. Renewable and Sustainable Energy Reviews 2013; 28: 702-14. http://dx.doi.org/10.1016/j.rser.2013.08.021

[2] Mao G, Huang N, Wang H, Research on biomass energy and environment from the past to the future: A bibliometric analysis. Science of The Total Environment 2018;635: 1081-90. https://doi.org/10.1016/j.scitotenv.2018.04.173

[3] Akyürek Z, Sustainable valorization of animal waste and recycled polyester: Co-pyrolysis synergy. Sustainability 2019; 11: 2280. doi:10.3390/su11082280

[4] Hughes E, Biomass cofiring: economics, policy and opportunities. Biomass and Bioenergy 2000; 19: 457-65. https://doi.org/10.1016/S0961-9534(00)00057-X

[5] Mao C, Yongzhong F, Xiaojiao W, Guangxin R, Review on research achievements of biogas from anaerobic digestion. Renewable and Sustainable Energy Reviews 2015; 45: 540-55. https://doi.org/10.1016/j.rser.2015.02.032

[6] Ladanai S, Vinterbäck J, Global Potential of Sustainable Biomass for Energy Report, 2009. https://pub.epsilon.slu.se/4523/1/ladanai_et_al_100211.pdf (Accessed December 17, 2018).

[7] World Energy Resources 2016, World Energy Council. https://www.worldenergy.org/wpcontent/uploads/2017/03/WEResources_Bioenergy_2016.pdf (Accessed December 17, 2018).

[8] Mahapatra S and Dasappa S, Influence of surface area to volume ratio of fuel particles on gasification process in a fixed bed. Energy for Sustainable Development 2014; 19: 122-9. https://doi.org/10.1016/j.esd.2013.12.013

[9] Kuhe A and Aliyu SJ, Gasification of 'Loose' Groundnut Shells in a Throathless Downdraft Gasifier. International Journal of Renewable Energy Development 2015; 4: 125-130. DOI: 10.14710/ijred.4.2.125-130

[10] Panwar NL, Kothari R, Tyagi VV, Thermo Chemical Conversion of Biomass-Eco Friendly Energy Routes. Renewable and Sustainable Energy Reviews 2012; 16: 1801-16. https://doi.org/10.1016/j.rser.2012.01.024

[11] Scalat N, Dallemand JF, Fahl F, Biogas: developments and perspectives in Europe. Renewable Energy 2018; Article in Press, https://doi.org/10.1016/j.renene.2018.03.006

[12] Lyytimäki J, Renewable energy in the news: Environmental, economic, policy and technology discussion of biogas. Sustainable Production and Consumption 2018; 15: 65-73. https://doi.org/10.1016/j.spc.2018.04.004

[13] Holm-Nielsen JB, AlSeadi T, Oleskowicz-Popie 1P, The future of anaerobic digestion and biogas utilization. Bioresource Technology 2009;100:5478-84. https://doi.org/10.1016/j.biortech.2008.12.046

[14] Nasir IM, Ghazi TIM, Omar R, Idris A, Anaerobic digestion of cattle manure: influence of in oculums concentration .Int J Engin Technol 2013;10: 22-6. ISSN 1823-1039 
[15] Biogas Potential in United States, 2013. https://www.nrel.gov/docs/fy14osti/60178.pdf (Accessed December 17, 2018).

[16] Ounnar A, Benhabyles L, Igoud S, Energetic valorization of biomethane pro-duced from cow-dung. Procedia Engineering 2012; 33:330-4. https://doi.org/10.1016/j.proeng.2012.01.1211

[17] De Vries JW, Vinken TMWJ, Hamelin L, DeBoer IJM. Comparing environmental consequences of anaerobic mono-and co-digestion of pig manure to produce bio-energy - a life cycle perspective. Bioresource Technology 2012; 125: 239-48. https://doi.org/10.1016/j.biortech.2012.08.124

[18] Abdeshahian P, Lim, JS, Ho WS, Hashim H, Lee CT, Potential of biogas production from farm animal waste in Malaysia, Renewable and Sustainable Energy Reviews 2016; 60: 714-23. http://dx.doi.org/10.1016/j.rser.2016.01.117

[19] Kumar M, Ou YL, Lin JG, Co-composting of green waste and food waste at low C/N ratio. Waste Management 2010; 30: 602-9. https://doi.org/10.1016/j.wasman.2009.11.023

[20] Zhu N, Effect of low initial $\mathrm{C} / \mathrm{N}$ ratio on aerobic composting of swine manure with rice straw, Bioresource Technology 2007; 98: 9-13. https://doi.org/10.1016/j.biortech.2005.12.003

[21] El-Mashad HM, Zhang RH, Biogas production from co-digestion of dairy manure and food waste. Bioresource Technology 2010; 101: 4021-8. https://doi.org/10.1016/j.biortech.2010.01.027

[22] Herrmann A, Biogas Production from Maize: Current State, Challenges and Prospects. 2. Agronomic and Environmental Aspects, BioEnergy Research 2013; 6: 372-387. DOI $10.1007 / \mathrm{s} 12155-012-9227-\mathrm{x}$

[23] Republic of Turkey Intended Nationally Determined Contribution http://www4.unfccc.int/submissions/INDC/Published\%20Documents/Turkey/1/The_INDC_of_T URKEY_v.15.19.30.pdf. (Accessed December 17, 2018).

[24] Republic of Turkey Ministry of Development. Tenth Development Plan of Turkey (2014-2018). http://www.sbb.gov.tr/wp-content/uploads/2018/11/Onuncu-Kalk\%C4\%B1nma-Plan\%C4\%B12014-2018.pdf (Accessed December 17, 2018).

[25] Turkish Electricity Transmission Corporation (TEİAŞ), https://www.teias.gov.tr/tr/i-kurulu-guc (Accessed December 17, 2018).

[26] Energy Map. Biogas power plants in Turkey. http://www.enerjiatlasi.com/ (Accessed December 17, 2018).

[27] Hijazi O, Munro S, Zerhusen B, Effenberger M, Review of life cycle assessment for biogas production in Europe, Renewable and Sustainable Energy Reviews 2016; 54: 1291-1300. http://dx.doi.org/10.1016/j.rser.2015.10.013

[28] Rios M, Kaltschmitt M, Electricity generation potential from biogas produced from organic waste in Mexico, Renewable and Sustainable Energy Reviews 2016; 54: 384-395. http://dx.doi.org/10.1016/j.rser.2015.10.033

[29] Abdeshahian P, Lim JS, Ho WS, Hashim H, Lee CT, Potential of biogas production from farm animal waste in Malaysia, Renewable and Sustainable Energy Reviews 2016; 60: 714-723. http://dx.doi.org/10.1016/j.rser.2016.01.117 
Akyürek / Eskişehir Technical Univ. J. of Sci. and Tech. A-Appl. Sci. and Eng. 20 (2) - 2019

[30] Avcioglu O, Turker U, Status and potential of biogas energy from animal wastes in Turkey, Renewable and Sustainable Energy Reviews 2012; 16: 1557-61. https://doi.org/10.1016/j.rser.2011.11.006

[31] Ilgar, R, A Study for Determination of Biogas Potential in Çanakkale, Assets by Animals, Eastern Geographical Review 2016, 35, 89-106. DOI: 10.17295/dcd.08733

[32] Eryilmaz, T, Yesilyurt, M.K, Gokdogan, O, Yumak, B, Determination of Biogas Potential from Animal Waste in Turkey: A Case Study for Yozgat Province, European Journal of Science and Technology 2015, 2 (4), 106-111. ISSN:2148-2683

[33] Özer, B, Biogas energy opportunity of Ardahan city of Turkey, Energy 2017, 139, 1144-1152. https://doi.org/10.1016/j.energy.2017.07.052

[34] Burdur Directorate of Provincial Agriculture and Forestry, 2018, https://burdur.tarim.gov.tr/Sayfalar/EN/AnaSayfa.aspx (Accessed December 17, 2018).

[35] Akyürek Z, Potential of biogas energy from animal waste in the Mediterranean Region of Turkey, Journal of Energy Systems 2018; 2(4): 159-167. DOI: 10.30521/jes.455325

[36] Ozyurt O, Energy issues and renewables for sustainable development in Turkey. Renewable and Sustainable Energy Reviews 2010; 14: 2976-2985. https://doi.org/10.1016/j.rser.2010.08.002

[37] Abdeshahian P, Lim JS, Ho WS, Hashim H, Lee CT, Potential of biogas production from farm animal waste in Malaysia, Renewable and Sustainable Energy Reviews 2016; 60: 714-723. http://dx.doi.org/10.1016/j.rser.2016.01.117

[38] Kuusik A, Pachel K, Kuusik A, Loigu, E, Possible agricultural use of digestate Proceedings of the Estonian Academy of Sciences 2017; 66: 64-74. https://doi.org/10.3176/proc.2017.1.10

[39] Guilayn F, Jimeneza J, Rouez M, Crest D, Patureaua D, Digestate mechanical separation: Efficiency profiles based on anaerobic digestion feedstock and equipment choice, Bioresource Technology 2019; 274: 180-9. https://doi.org/10.1016/j.biortech.2018.11.090 